\title{
Aspirin-induced nuclear translocation of NF $\kappa$ B and apoptosis in colorectal cancer is independent of p53 status and DNA mismatch repair proficiency
}

\author{
FVN Din', LA Stark' and MG Dunlop*,I \\ 'Colon Cancer Genetics Group, Department of Oncology, Division of Clinical and Molecular Medicine and MRC Human Genetics Unit, Western General \\ Hospital, University of Edinburgh, Crewe Rd, Edinburgh EH4 2XU, Scotland
}

\begin{abstract}
Substantial evidence indicates nonsteroidal anti-inflammatory drugs (NSAIDs) protect against colorectal cancer (CRC). However, the molecular basis for this anti-tumour activity has not been fully elucidated. We previously reported that aspirin induces signal-specific $\mid \kappa \mathrm{B} \alpha$ degradation followed by $\mathrm{NF} \kappa \mathrm{B}$ nuclear translocation in CRC cells, and that this mechanism contributes substantially to aspirininduced apoptosis. We have also reported the relative specificity of this aspirin-induced NF $\kappa$ B-dependent apoptotic effect for CRC cells, in comparison to other cancer cell types. It is now important to establish whether there is heterogeneity within CRC, with respect to the effects of aspirin on the NF $\kappa$ B pathway and apoptosis. p53 signalling and DNA mismatch repair (MMR) are known to be deranged in CRC and have been reported as potential molecular targets for the anti-tumour activity of NSAIDs. Furthermore, both $\mathrm{p} 53$ and MMR dysfunction have been shown to confer resistance to chemotherapeutic agents. Here, we set out to determine the p53 and hMLHI dependency of the effects of aspirin on NF $\kappa$ B signalling and apoptosis in CRC. We specifically compared the effects of aspirin treatment on cell viability, apoptosis and NF $\kappa$ B signalling in an HCT-II6 CRC cell line with the p53 gene homozygously disrupted ( $\mathrm{HCT}-116^{\mathrm{p}^{53-1-}}$ ) and an HCT-I16 cell line rendered MMR proficient by chromosomal transfer (HCT$116^{+\mathrm{ch} 3}$ ), to the parental HCT-I I6 CRC cell line. We found that aspirin treatment induced apoptosis following $\mid \kappa B \alpha$ degradation, $\mathrm{NF} \kappa \mathrm{B}$ nuclear translocation and repression of $\mathrm{NF} \kappa \mathrm{B}$-driven transcription, irrespective of p53 and DNA MMR status. These findings are relevant for design of both novel chemopreventative agents and chemoprevention trials in CRC.
\end{abstract}

British Journal of Cancer (2005) 92, I |37- | |43. doi: | 0.1038/sj.bjc.6602455 www.bjcancer.com

Published online 15 March 2005

(C) 2005 Cancer Research UK

Keywords: NF- $\kappa$ B; p53; mismatch repair; NSAIDs; colorectal cancer

Ingestion of nonsteroidal anti-inflammatory drugs (NSAIDs) has been shown to be associated with a $40-50 \%$ reduction in relative risk of colorectal cancer (CRC) (Thun et al, 1993). There is much research effort focussed on the molecular mechanisms involved in NSAID anti-tumour activity. Such understanding would inform the rational design of novel agents both for chemoprevention and therapy.

We previously reported the pivotal involvement of the transcription factor $\mathrm{NF} \kappa \mathrm{B}(\mathrm{p} 50-\mathrm{p} 65)$ in aspirin-mediated apoptosis in CRC cells (Stark et al, 2001). NF $\kappa \mathrm{B}$ is sequestered in the cytoplasm, bound to a member of the $\mathrm{I} \kappa \mathrm{B}$ family of inhibitory proteins. Stimulation by one of a range of signals results in phosphorylation and ubiquitination of $\mathrm{I} \kappa \mathrm{B}$ followed by proteosome-mediated degradation. Dissociation from $\mathrm{I} \kappa \mathrm{B}$ results in $\mathrm{NF} \kappa \mathrm{B}$ nuclear translocation and transcriptional regulation of numerous target genes. $\mathrm{NF} \kappa \mathrm{B}$ has been shown to have both proand anti-apoptotic effects (Barkett and Gilmore, 1999). Such

\footnotetext{
*Correspondence: Professor MG Dunlop;

E-mail: Malcolm.Dunlop@hgu.mrc.ac.uk

Revised 17 January 2005; accepted 19 January 2005; published online 15 March 2005
}

disparate effects are due to differences in stimuli, $\mathrm{NF} \kappa \mathrm{B}$ composition, cell type and distinct $\kappa \mathrm{B}$ binding specificities of individual complexes resulting in diverse target gene specificity (Epinat and Gilmore, 1999). We have previously shown that aspirin-mediated apoptosis in CRC cells involves $\mathrm{I} \kappa \mathrm{B} \alpha$ degradation and $\mathrm{NF} \kappa \mathrm{B}$ nuclear translocation (Stark et al, 2001). We also demonstrated that aspirin-induced $\mathrm{I} \kappa \mathrm{B} \alpha$ degradation was required for apoptosis because cells constitutively expressing super-repressor $\mathrm{I} \kappa \mathrm{B} \alpha$ were resistant to both aspirin-induced $\mathrm{NF} \kappa \mathrm{B}$ nuclear translocation and apoptosis. More recently, we have reported the relative specificity of this NF $\kappa \mathrm{B}$-dependent apoptotic effect of aspirin for CRC cells, when compared to other cancer cell types (Din et al, 2004). However, it is also important to determine whether there is heterogeneity within CRC, with respect to the effects of aspirin on the NF $\kappa \mathrm{B}$ pathway and apoptosis.

It is now well established that genomic instability, by increasing mutational load, promotes neoplastic progression in CRC. The p53 tumour suppressor gene is involved in cell cycle control, apoptosis and maintenance of genomic stability and is frequently mutated in colorectal tumours, heralding malignant transformation (Baker et al, 1989, 1990; Honma et al, 2000). Another important contributor to genomic instability is defective DNA mismatch 
repair (MMR) resulting in microsatellite instability (MSI) (Veig et al, 1998). MSI is the hallmark of tumours arising in hereditary nonpolyposis colorectal cancer (HNPCC) and is also found in 15\% of sporadic CRCs (Boland et al, 1998; Brown et al, 1998). The majority of MSI tumours in familial cases are due to germline mutations in hMLH1, hMLH2 and hMSH6 genes, and to hMLH1 promoter hypermethylation in sporadic cancers (Kuismanen et al, 2000). p53 dysfunction and DNA MMR deficiency are almost wholly mutually exclusive (Cottu et al, 1996; Samowitz et al, 2001). p53 signalling and DNA MMR have been identified as potential molecular targets for NSAIDs (Ruschoff et al, 1998; Shao et al, 2000; Goel et al, 2003), suggesting that the anti-tumour effect may, in part, involve countering the effects of genetic instability in CRC. Such genetic aberrations in tumours have also been shown to be involved in determining response to chemotherapeutic agents (O’Connor et al, 1997; Weller, 1998; Ribic et al, 2003).

In light of the importance of p53 and MMR in CRC and that genomic instability can influence response to chemotherapeutics, we set out to determine the p53 and hMLH1 dependency of the effects of aspirin on $\mathrm{NF} \kappa \mathrm{B}$ signalling. Our findings suggest that the $\mathrm{NF} \kappa \mathrm{B}$-apoptotic response to aspirin occurs irrespective of $\mathrm{p} 53$ status and MMR defects and shed further light on the chemopreventive action of NSAIDs.

\section{MATERIALS AND METHODS}

\section{Cell line culture and treatment}

The CRC cell line HCT-116 (genotype p53 $(+/+)$, hMLH1 $(-))$, is available from the American Type Culture Collection (ATCC). The HCT-116 cell line has a hemizygous mutation in hMLH1 resulting in a truncated, nonfunctional protein. The HCT-116 subline where hMLH1 expression is restored by chromosome 3 transfer (HCT116 $^{+\mathrm{ch} 3}$, genotype p53 $(+/+)$, hMLH1 $\left.(+)\right)$ was a gift from Professor CR Boland and these cells are competent in DNA MMR (Koi et al, 1994). The p53 null HCT-116 subline (HCT$\left.116^{\mathrm{p} 53-l-}\right)$ was created by targeted homologous recombination (Bunz et al, 1999) and was a gift from Professor B Vogelstein. All three cell lines were grown in McCoy's 5A media and the HCT$116^{+\mathrm{ch} 3}$ cell line was grown under selection with $0.4 \mathrm{mg} \mathrm{ml}^{-1}$ geneticin. All media were supplemented with $10 \%$ foetal calf serum (FCS) and 1\% penicillin/streptomycin (media supplied by Gibco $\mathrm{BRL}$, Paisley, UK) and cells were grown as monolayers $\left(37^{\circ} \mathrm{C}\right.$ in $5 \%$ $\left.\mathrm{CO}_{2}\right)$. Cells were plated $\left(1 \times 10^{6}\right.$ cells $/ 50 \mathrm{ml}$ flask $)$ and grown until $60-70 \%$ confluent. Aspirin (Sigma, St Louis, USA) was prepared as a $0.5 \mathrm{M}$ stock solution in distilled water (final $\mathrm{pH} 7.0$ ). Prior to treatment for $16 \mathrm{~h}$ with aspirin $(1,3,5$ and $10 \mathrm{~mm})$ or carrier control (at same concentrations as aspirin), the growth medium was replaced with the respective low serum $(0.5 \%$ FCS $)$ medium.

\section{Cell viability and determination of apoptosis}

After aspirin treatment, adherent cells were harvested and viable cell number determined by counting with a haemocytometer. Cell surface phosphatidylserine is a marker for apoptosis and was detected via its interaction with annexin V using the Annexin VFITC apoptosis detection kit (Oncogene Research Products, Cambridge, MA, USA), as per the manufacturer's instructions. Briefly, the media from the flask of adherent cells was transferred to a conical tube on ice to harvest any floating cells. Cells were then washed with $2 \mathrm{ml}$ of PBS, which was also added to the tube to collect any cells dislodged during washing. Cells were incubated with $1 \mathrm{ml}$ of trypsin: versene (volume per volume) just until the cells detached and then resuspended in the conical tube containing the media with the floating and washed cells. Cells were counted using a haemocytometer and resuspended in cold $1 \times$ binding buffer to approximately $1 \times 10^{6} \mathrm{cells}^{-1}$. Media binding reagent
$(10 \mu \mathrm{l})$ was added to $0.5 \mathrm{ml}$ of the cell suspension, which was incubated with $1.25 \mu \mathrm{l}$ of annexin V-FITC for $15 \mathrm{~min}$ at room temperature in the dark. Annexin $\mathrm{V}$ was then removed by centrifugation at $1000 \times \mathbf{g}$ for $5 \mathrm{~min}$ and the cells were resuspended in $0.5 \mathrm{ml}$ of cold $1 \times$ binding buffer and placed on ice. The counting was carried out using a haemocytometer (two counting grids) in duplicate and this was carried out immediately following staining of cells as apoptosis is an ongoing process and the FITC signal may be lost after an hour.

\section{Western blotting}

After aspirin treatment, cells were washed with PBS, centrifuged (1200 r.p.m. for $10 \mathrm{~min}$ ) and cell pellets were resuspended in lysis buffer $(50 \mathrm{~mm} \mathrm{NCl}, 10 \mathrm{~mm}$ HEPES, $500 \mathrm{~mm}$ sucrose, $1 \mathrm{~mm}$ EDTA, $0.5 \mathrm{~mm}$. spermidine, $0.15 \mathrm{~mm}$ spermine, $0.2 \%$ Triton $\mathrm{X}-100$, Complete Protease Inhibitor Cocktail (Roche Diagnostics, Manheim, Germany), $100 \mathrm{~mm}$ Pefabloc (Roche Diagnostics, Manheim, Germany)). The cell suspension was centrifuged (6000 r.p.m. for $15 \mathrm{~min}, 4^{\circ} \mathrm{C}$ ) and the supernatant used as cytoplasmic extract. Protein content was measured by the method of Bradford (BioRad, Hercules, CA, USA).

Cytoplasmic proteins $(30 \mu \mathrm{g})$ were separated on a $10 \%$ SDS PAGE gel, transferred to a polyvinylidine difluoride membrane (BioRad) and blocked in $4 \%$ non-fat dry milk solution with $0.3 \%$ Tween20 (Sigma). Membranes were probed with a sheep polyclonal $\mathrm{I} \kappa \mathrm{B} \alpha$ antibody (a gift from Professor R Hay, University of St Andrews, UK) and then with monoclonal antibody to $\mathrm{Cu} / \mathrm{Zn}$ SOD (The Binding Site, Birmingham, UK) as a control for protein loading. Chemiluminescence was used to visualise the antigen-antibody complexes (Amersham ECL Reagents, Little Chalfont, UK).

\section{Electrophoretic mobility shift assays}

Electrophoretic mobility shift assays were carried out by incubating nuclear extracts from untreated cells $(6 \mu \mathrm{g})$ with binding reaction mix $(1 \times$ binding buffer $(50 \mathrm{~mm} \mathrm{KCl,} 20 \mathrm{~mm}$ HEPES, $5 \%$ glycerol, $1 \mathrm{~mm}$ EDTA, $1 \mathrm{mM}$ DTT), $1 \mu \mathrm{g}$ BSA, $1 \mu \mathrm{g}$ poly dI-dC, $25 \mathrm{fmol}$ radioactively labelled oligo-DNA in a final volume of $20 \mu \mathrm{l}$ ) for $30 \mathrm{~min}$ prior to analyses on a $4 \%$ native polyacrylamide gel. Double-stranded oligonucleotides for $\mathrm{NF} \kappa \mathrm{B}$ were obtained from Santa Cruz.

\section{Immunofluorescence analysis}

Cells grown to $60-70 \%$ confluence on glass coverslips were treated with carrier or $10 \mathrm{~mm}$ aspirin for $16 \mathrm{~h}$ (in respective $0.5 \%$ FCS medium). After treatment, cells were washed with PBS, fixed with acetone: methanol (volume per volume) $\left(-20^{\circ} \mathrm{C}, 10 \mathrm{~min}\right)$ and blocked in $10 \%$ nonimmune donkey serum (Sigma) for $1 \mathrm{~h}$. Rabbit polyclonal antibody to $\mathrm{NF} \kappa \mathrm{B}$ p65 (Santa Cruz) was applied for $1 \mathrm{~h}$ followed by incubation with FITC-conjugated donkey anti-rabbit IgG for $1 \mathrm{~h}$. The nuclei were stained with DAPI and the coverslips mounted with Vectashield (Vector Laboratories, Burlingame, California, USA).

\section{Transfections and reporter assays}

For transient transfection experiments, $50 \mathrm{ml}$ flasks of cells were grown to subconfluency then transfected with $6 \mu \mathrm{g}$ of luciferase reporter plasmid and $3 \mu \mathrm{g}$ of $\beta$-galactosidase control plasmid, using Lipofectamine as described by the manufacturer's instructions (Gibco BRL). Following transfection, cells were grown in low serum $(0.5 \%$ FCS $)$ medium then treated with aspirin $(0-10 \mathrm{mM})$ for $16 \mathrm{~h}$. Luciferase activity was measured in cell extracts using a luciferase reporter assay kit (Promega) and read using a luminometer. Transfection efficiency and cell viability were 
monitored by cotransfection with a CMV- $\beta$-galactosidase reporter plasmid and $\beta$-galactosidase activity was quantified with an assay kit (Promega), as per the manufacturer's instructions. Relative luciferase activity was calculated as unit of luciferase activity per unit of $\beta$-galactosidase activity.

\section{RESULTS}

Basal expression of $\mathrm{I} \kappa \mathrm{B} \alpha$ and $\mathrm{p} 65$ proteins in CRC cell lines is independent of p53 and hMLH1 expression

To investigate the relationship between p53 and MMR status and the $\mathrm{NF} \kappa \mathrm{B}$-dependent apoptotic response to aspirin, we used the following three CRC cell lines: parental HCT-116 cells (wild-type p53, hMLH1 deficient), HCT-116 ${ }^{+c h 3}$ (wild-type p53, hMLH1 proficient) and HCT-116 ${ }^{\mathrm{p} 53-1-}$ (p53 null, hMLH1 deficient). The presence of hMLH1 in the HCT-116 ${ }^{+\mathrm{ch} 3}$ cell line and the absence of $\mathrm{p} 53$ in the HCT-116 $\mathrm{p}^{\mathrm{p} 53-/-}$ cell line was verified by immunoblot analysis (Figure 1A). Firstly, we considered whether p53 and hMLH1 mutation status might affect basal levels of $\mathrm{I} \kappa \mathrm{B} \alpha$ and $\mathrm{p} 65$ proteins. Using immunoblot analysis of cytoplasmic extracts, we found there were no significant differences in expression of $\mathrm{I} \kappa \mathrm{B} \alpha$ or p65, or their relative levels (data not shown), between the three CRC cell lines (Figure 1B). These results indicate that changes in MMR mutation status and p53 expression do not affect the
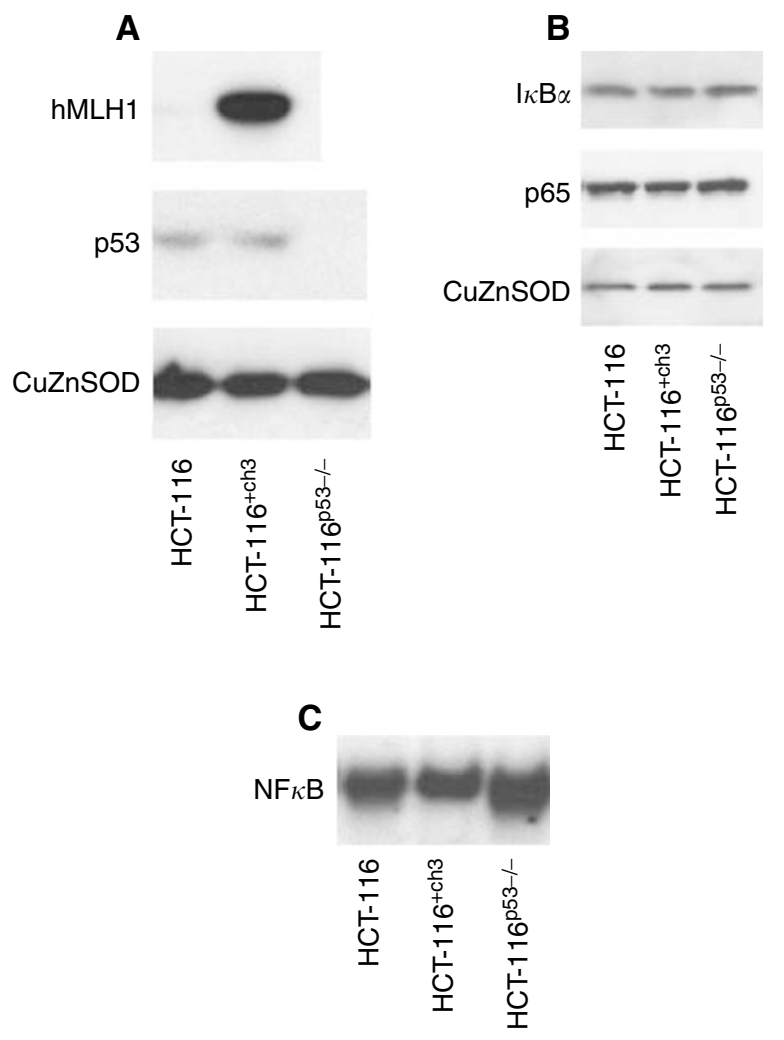

Figure I Basal expression of $\mathrm{p} 53, \mathrm{hMLHI}, \mid \kappa \mathrm{B} \alpha$ and $\mathrm{p} 65$ in untreated colorectal cancer cell lines. Cytoplasmic extracts were made from untreated cells and Western blots probed with p53 and hMLHI antibodies to confirm the expression profile of the cell lines $(\mathbf{A})$. Cytoplasmic extracts were probed with sheep polyclonal $\mid \kappa \mathrm{B} \alpha$ and rabbit polyclonal p65 antibodies to examine the basal expression of proteins in the cell lines (B). The Western blots shown are representative of at least three independent experiments and $\mathrm{Cu} / \mathrm{Zn}$ SOD was used as a control for protein loading. Electrophoretic mobility shift assay using NF $\kappa$ B consensus oligonucleotide, performed on nuclear extracts of untreated cells, demonstrated basal NF $\kappa$ B DNA binding activity $(\mathbf{C})$. cytoplasmic pool of either protein available for stimulation. We next considered whether basal levels of $\mathrm{NF} \kappa \mathrm{B}$ DNA binding were affected by changes in p53 or MMR status. Electrophoretic mobility shift assays (EMSAs) performed on nuclear extracts of untreated cells showed basal NF $\kappa$ B DNA binding in the three CRC cell lines (Figure 1C). The differences in basal levels of NF $\kappa$ B DNA binding complexes in the HCT-116 ${ }^{+\mathrm{ch} 3}$ and HCT-116 $6^{\mathrm{p} 53-1-}$ cell lines compared to the parental HCT-116 cell line were marginal (densitometry data not shown).

\section{Aspirin induces apoptosis in CRC cell lines independent of p53 and MMR status}

To determine whether p53 and MMR status affects the aspirinmediated reduction in cell viability we have previously observed, we compared the effects of aspirin treatment on the viability of HCT- $116^{+ \text {ch } 3}$ and HCT- $116^{\mathrm{p}^{53-}-}$ cell lines to the parental HCT116 cell line. In triplicate dose-response experiments, all CRC cell lines were treated for $16 \mathrm{~h}$ with aspirin $(1,3,5$ and $10 \mathrm{~mm})$ and viable cell number determined by haemocytometric counts. Aspirin treatment resulted in a concentration-dependent decrease in the number of viable cells in all three CRC cell lines (Figure 2A). Furthermore, the cell lines showed proportionate decreases in cell viability at each concentration increment, indicating a similar sensitivity to aspirin, irrespective of p53 or MMR status (Figure $2 \mathrm{~B}$ ). The $\mathrm{IC}_{50}$ values were calculated from the growth curves of the aspirin-treated CRC cell lines (Table 1) and there were no significant differences in levels of cell death with each genetic background.

It is well established that aspirin induces apoptosis in CRC cell lines (Piazza et al, 1995; Qiao et al, 1998; Stark et al, 2001; Din et al, 2004). We next confirmed that the reduction in viable cell number in each of the cell lines was indeed due to apoptosis for all three genotypes, and not simply a growth inhibitory effect. Following aspirin treatment, cells were stained with Annexin V, which binds phosphatidylserine residues that are externalised during apoptosis and thus serves as a marker for programmed cell death. Consistent with the reduction in cell viability, we found that aspirin induced a concentration-dependent increase in the proportion of apoptotic cells in all three CRC cell lines (Figure 2C). Furthermore, there was no significant difference in apoptotic response between any of the HCT-116, HCT- $116^{+\mathrm{ch} 3}$ and HCT-116 ${ }^{\mathrm{p} 53-1-}$ cell lines. In addition there was good correlation between the $\mathrm{IC}_{50}$ value and apoptotic response; the lower the $\mathrm{IC}_{50}$ value, indicating greater sensitivity at a lower aspirin concentration, the greater the fold increase in apoptosis $(r=-0.98)$. These data suggest that aspirin-mediated apoptosis in CRC cells is independent of p53 and MMR status.

\section{Aspirin induces $\mathrm{I} \kappa \mathrm{B} \alpha$ degradation and NF $\kappa \mathrm{B}$ nuclear translocation in CRC cell lines irrespective of p53 and MMR status}

Having shown previously that p65 nuclear translocation is a critical event in effecting the apoptotic response to aspirin (Stark et al, 2001), we next studied the effect of aspirin on $\mathrm{NF} \kappa \mathrm{B}$ signalling in each cell line. Since $\mathrm{I} \kappa \mathrm{B} \alpha$ sequesters $\mathrm{NF} \kappa \mathrm{B}$ in the cytoplasm, we first investigated the effect of aspirin treatment on the cytoplasmic levels of $\mathrm{I} \kappa \mathrm{B} \alpha$ in each cell line using immunoblot analysis. We found that aspirin treatment induced degradation of $\mathrm{I} \kappa \mathrm{B} \alpha$ in a similar concentration-dependent manner in each cell line genotype (Figure $3 \mathrm{~A}$ ). We next determined whether the $\mathrm{I} \kappa \mathrm{B} \alpha$ degradation was accompanied by $\mathrm{NF} \kappa \mathrm{B}$ nuclear translocation in the CRC cell lines. Immunofluorescence analysis showed that following $16 \mathrm{~h}$ aspirin exposure, p65 translocated from the cytoplasm to the nucleus in each cell line, irrespective of p53 and MMR status (Figure 3B). These findings indicate that aspirininduced apoptosis, due to modulation of the $\mathrm{NF} \kappa \mathrm{B}$ pathway, 

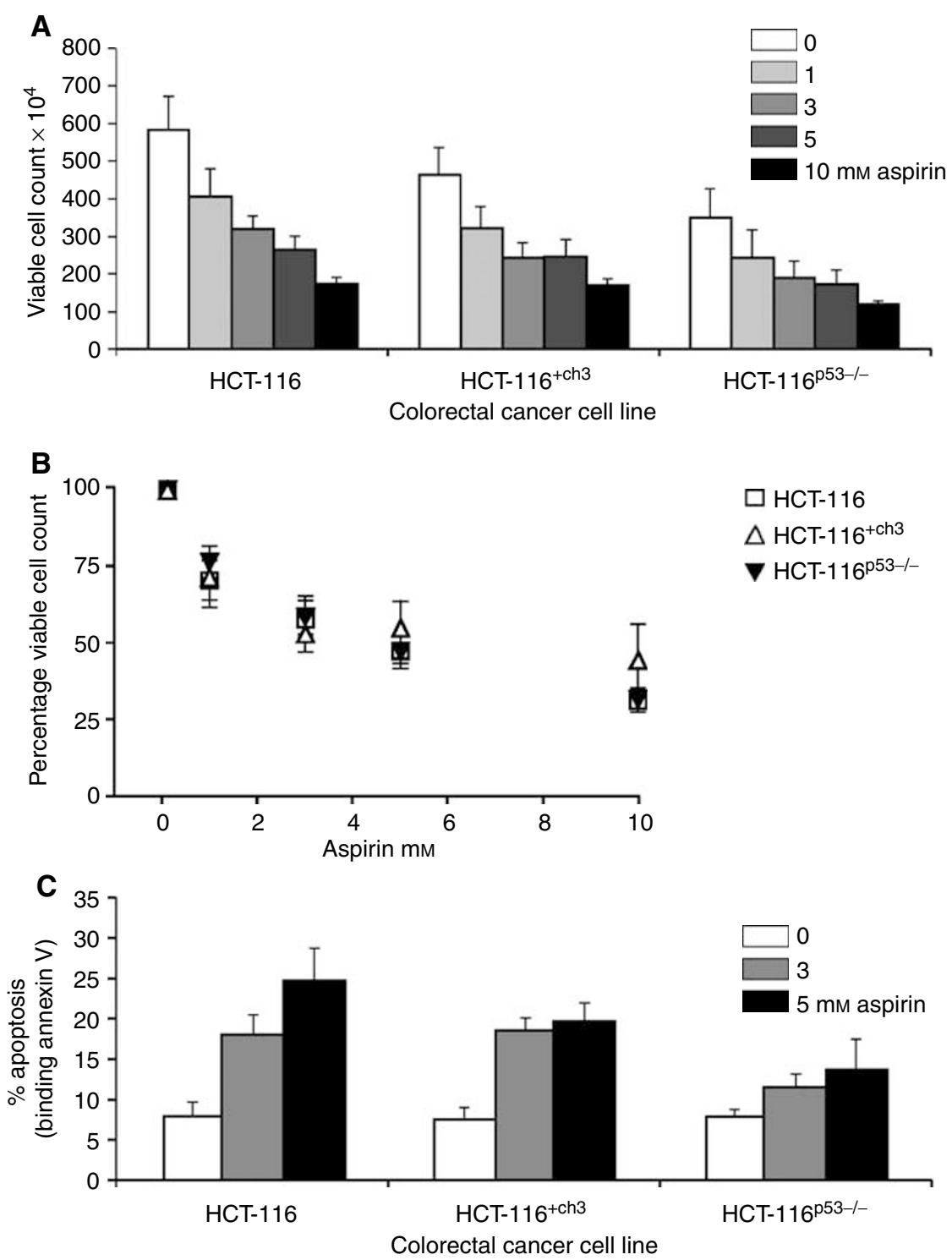

Figure 2 Effect of aspirin on cell viability and apoptosis in colorectal cancer (CRC) cell lines. Aspirin treatment $(0-10 \mathrm{~mm})$ for $16 \mathrm{~h}$ induces a concentration-dependent decrease in viable cell number (determined by haemocytometric counts) in all CRC cell lines (A). The decrease in cell viability is proportionate at each concentration increment indicating a similar pattern of response following aspirin treatment in each cell line (B). Annexin $V$ binding assay used to determine that all CRC cell lines undergo apoptosis after aspirin treatment $(0-5 \mathrm{mM})(\mathbf{C})$. The graphs represent three independent experiments and the bars on the graphs are standard error bars.

occurs irrespective of derangements in p53 signalling and the MMR system.

\section{Aspirin-mediated repression of $\mathrm{NF} \kappa \mathrm{B}-$ driven reporter activity is unrelated to p53 and MMR status}

We have previously demonstrated aspirin-induced nuclear translocation of $\mathrm{NF} \kappa \mathrm{B}$ results in repression of $\mathrm{NF} \kappa \mathrm{B}$ transcriptional activity in CRC cell lines (Stark et al, 2000). This was recently substantiated by the finding that $\mathrm{NF} \kappa \mathrm{B}$ induced by some cytotoxic stimuli acts as an active repressor of anti-apoptotic gene expression (Campbell et al, 2004). The effect of aspirin on $\mathrm{NF} \kappa \mathrm{B}$-driven transcription was investigated to determine whether p53 or MMR mutation status affects the ability of aspirin to induce $\mathrm{NF} \kappa \mathrm{B}$ transcriptional repression in CRC cells. The cell lines were transiently transfected with the 3enhancer-ConA NF $\kappa \mathrm{B}$-dependent luciferase reporter construct in which transcription of the firefly luciferase gene is driven by three $\kappa \mathrm{B}$ binding sites (Roff et al, 1996). A reporter plasmid with deleted $\kappa \mathrm{B}$ sites served as control. Following transfection, cells were exposed to aspirin for $16 \mathrm{~h}$. There was a substantial decrease in the basal levels of $\mathrm{NF} \kappa \mathrm{B}$-driven reporter activity following aspirin exposure and this was observed in a concentration-dependent manner, irrespective of p53 or MMR status (Figure 4). These findings show that aspirin-induced repression of $\mathrm{NF} \kappa \mathrm{B}$ transcriptional activity, and hence downstream regulation of target genes, is independent of p53 signalling and DNA MMR.

\section{DISCUSSION}

We previously reported that the effects of aspirin on $\mathrm{NF} \kappa \mathrm{B}$ signalling are a centrally important mechanism of aspirinmediated apoptosis in CRC cells (Stark et al, 2001; Din et al, 
Table I $\quad I_{50}$ values for colorectal cancer cell lines

\begin{tabular}{|c|c|c|c|}
\hline \multirow[b]{2}{*}{ CRC cell line } & \multirow[b]{2}{*}{$\mathrm{IC}_{50}$} & \multicolumn{2}{|c|}{ Fold increase apoptosis } \\
\hline & & $3 \mathrm{~mm}$ & $5 \mathrm{~mm}$ \\
\hline HCT-II6 & 2.8 & 2.3 & 3.1 \\
\hline HCT-1 $16^{+c h 3}$ & 3.1 & 2.4 & 2.6 \\
\hline HCT- $116^{\mathrm{p} 53-1-}$ & 4.3 & 1.5 & 1.8 \\
\hline
\end{tabular}

Cells were treated with aspirin $(1,3,5,10 \mathrm{~mm})$ for $16 \mathrm{~h}$ and cell numbers determined as described in Materials and Methods. There is an inverse correlation between $\mathrm{IC}_{50}$ values and the fold increase in apoptosis at both 3 and $5 \mathrm{mM}(r=-0.93$ and -0.98$)$. Results are mean of at least three different experiments.
A

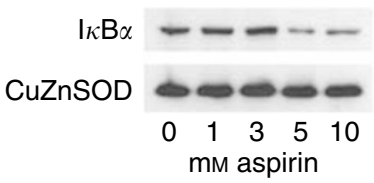

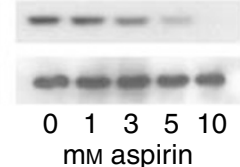

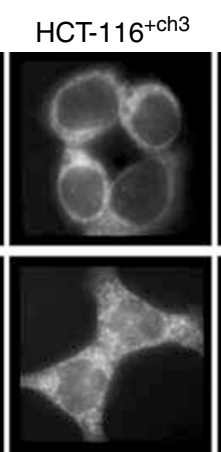

HCT-116 ${ }^{+\mathrm{ch} 3}$

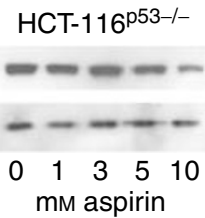

HCT-116 ${ }^{\text {p53-/- }}$

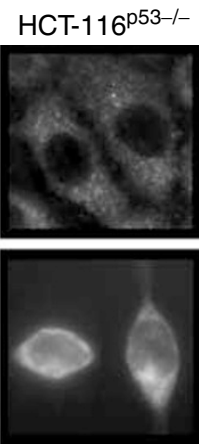

Figure 3 Aspirin induces $\mid \kappa B \alpha$ degradation and nuclear translocation of p65 in colorectal cancer (CRC) lines. Following aspirin treatment, cytoplasmic extracts were made from untreated and treated cells and probed with sheep polyclonal $\mid \kappa \mathrm{B} \alpha$ antibody. Western blot analysis shows that aspirin treatment $(0-10 \mathrm{~mm})$ for $16 \mathrm{~h}$ induces $1 \kappa \mathrm{B} \alpha$ degradation in a concentration-dependent manner in the HCT-II6, HCTII6 $6^{\text {ch } 3}$ and HCT-11 $6^{\text {P53-1- }}$ CRC cell lines $(\mathbf{A})$. The Western blot shown is representative of at least three independent experiments and $\mathrm{Cu} / \mathrm{Zn}$ SOD was used as a control for protein loading. Micrographs $(63 \times)$ of immunocytochemically stained cells show that aspirin treatment $(10 \mathrm{mM})$ for $16 \mathrm{~h}$ induces nuclear accumulation of p65 in the HCT-116, $\mathrm{HCTI} 16^{+\mathrm{ch} 3}$ and HCT- $116^{\mathrm{P} 53-1-} \mathrm{CRC}$ cell lines $(\mathbf{B})$.

2004). This work considerably extends these previous observations since we have shown that the effect of aspirin on apoptosis and $\mathrm{NF} \kappa \mathrm{B}$ signalling is independent of p53 and DNA MMR status. Furthermore, we show that aspirin induces nuclear translocation of $\mathrm{p} 65$ that is associated with repression of $\kappa \mathrm{B}$-driven transcription, again independent of p53 or MMR status.

It is well established that aspirin has a chemopreventive effect in CRC, but the mechanism of action has not been fully characterised. It is apparent that inhibition of the cyclooxygenase- 2 enzyme (COX-2) plays a part in the anti-tumour effect of NSAIDs in CRC (Marnett and DuBois, 2002). However, it is also clear that there are other important mechanisms involved since the growth inhibitory and apoptotic effects of NSAIDs occur in CRC cell lines that do not express COX-2 (Hanif et al, 1996; Elder et al, 1997). Furthermore, NSAIDs that lack COX-2 activity are growth inhibitory and also induce apoptosis in CRC cells (Piazza et al, 1995, 1997; Elder et al, 1997). It has also been shown that NSAID concentrations required for growth inhibition differ from those for COX-2 enzyme inhibition (Charalam- bous and O'Brien, 1996; Hanif et al, 1996). Taken together, such evidence indicates that while COX-2 inhibition is important, there are other essential mechanism(s) of action. p53 function and DNA MMR have been proposed as potential targets responsible for the anti-tumorigenic properties of NSAIDs (Ruschoff et al, 1998; Shao et al, 2000).

The p53 signalling pathway is central to regulating cell growth and death, and stabilisation of p53 by mutation is a key event occurring late in colorectal tumorigenesis (Baker et al, 1990). Several studies have shown an association between p53 mutation status and sensitivity to chemotherapeutic drugs in colorectal and other cancers (O'Connor et al, 1997; Weller, 1998). The p53 pathway has been postulated as a potential target since NSAIDs have been shown to alter levels of p53 (Goldberg et al, 1996; Kralj et al, 2001). Furthermore, there is evidence for regulatory interdependence between $\mathrm{p} 53$ and $\mathrm{NF} \kappa \mathrm{B}$ involving competition for common coactivators (Wu and Lozano, 1994; Webster and Perkins, 1999). Indeed, wild-type p53 has been shown to suppress constitutive $\mathrm{NF} \kappa \mathrm{B}$ activity and lead to apoptosis (Shao et al, 2000), suggesting that tumours expressing wild-type p53 may be more susceptible to aspirin-induced apoptosis.

Our previous work indicated that CRC cell lines expressing wildtype p53 were not more sensitive to aspirin-induced apoptosis mediated by $\mathrm{NF} \kappa \mathrm{B}$ signalling, but there are differences other than p53 status between the cell lines studied (Din et al, 2004). In this study, we specifically investigated the effects of p53 on the $\mathrm{NF} \kappa \mathrm{B}$-induced apoptotic response by use of HCT-116 cells with the p53 gene homozygously disrupted by targeted homologous recombination (Bunz et al, 1999). Using this approach, we have shown that aspirin-induced apoptosis is independent of p53 in CRC cells. Furthermore, p53 does not appear to play a role in aspirin-induced effects on $\mathrm{NF} \kappa \mathrm{B}$ signalling or on the repression of $\mathrm{NF} \kappa \mathrm{B}$ transcriptional activity. These findings are important in terms of chemoprevention since p53 mutant CRCs have been shown to differ in behaviour from those expressing wild-type $\mathrm{p} 53$, with respect to response to chemotherapeutic agents and prognosis.

Defective DNA MMR is characteristic of HNPCC and around $15 \%$ of sporadic CRCs also exhibit genetic instability, mainly due to epigenetic silencing of hMLH1 but also to somatic MMR gene defects (Herman et al, 1998). The DNA MMR system has been implicated as a potential pathway for modulation that may contribute to NSAID anti-tumour activity (Ruschoff et al, 1998; Goel et al, 2003). Our previous work suggested that MMR proficient cells may be more sensitive to aspirin-induced apoptosis since the MMR-deficient cell lines had greater $\mathrm{IC}_{50}$ values than MMR-proficient cell lines (Din et al, 2004). Hence, we examined whether MMR status influenced $\mathrm{NF} \kappa \mathrm{B}$-dependent aspirin-induced apoptosis, by comparing the MMR-deficient HCT-116 to its proficient counterpart HCT $116^{+\mathrm{ch} 3}$. We observed a dose-dependent increase in apoptosis after treatment with aspirin following $\mathrm{I} \kappa \mathrm{B} \alpha$ degradation, $\mathrm{NF} \kappa \mathrm{B}$ nuclear translocation and repression of $\mathrm{NF} \kappa \mathrm{B}$-driven transcription in both cell lines. The parental HCT-116 cells, which are MMR deficient, did appear to have a marginally lower $\mathrm{IC}_{50}$ value and show a greater fold increase in apoptosis when compared to the MMR-proficient cell line, but this was not significant (Table 1). Although we did not detect any significant differences in the NF $\kappa \mathrm{B}$-dependent apoptotic response to aspirin attributable to MMR status, long-term in vitro aspirin exposure has been shown to select for microsatellite stability in colorectal and gastric cancer cell lines (Ruschoff et al, 1998; Yamamoto et al, 1999). It has also recently been shown that aspirin treatment increased MMR protein expression and apoptosis in CRC cell lines (Goel et al, 2003). However, we found no evidence that MMR status influences the $\mathrm{NF} \kappa \mathrm{B}$-dependent apoptotic response, suggesting that the MMR system is not the predominant pathway responsible for NSAID anti-tumour activity. 


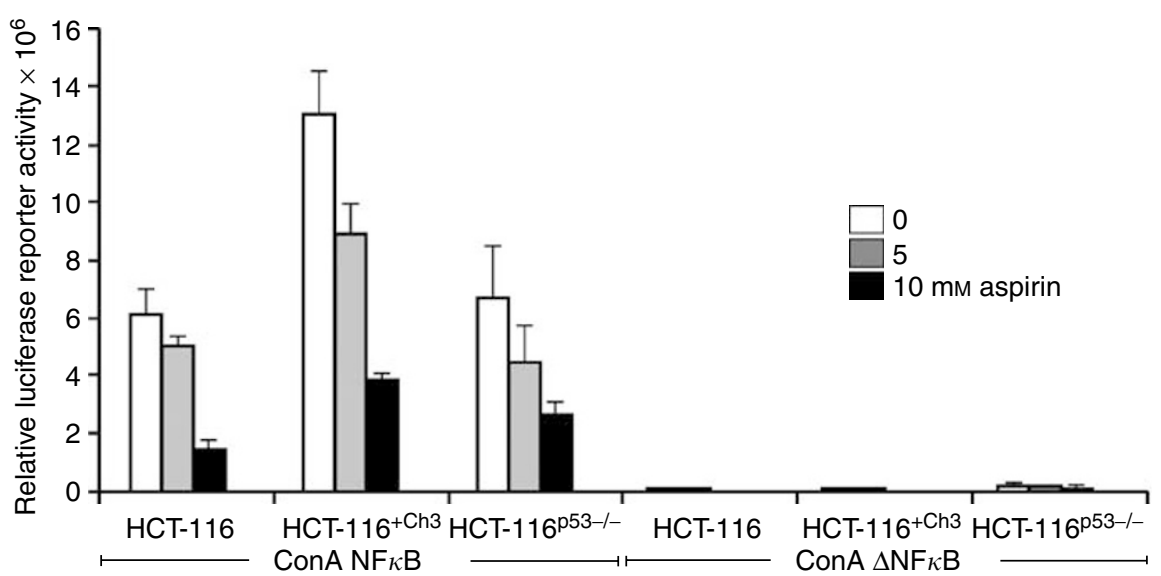

Figure 4 Aspirin induces repression of $N F \kappa B$-driven transcription in colorectal cancer $(C R C)$ lines. $C R C$ cells were transfected with the ConA $N F \kappa B$ dependent luciferase reporter construct, containing three $\kappa \mathrm{B}$ binding sites, or the equivalent plasmid with $\kappa \mathrm{B}$ consensus sites deleted (ConA $\Delta \kappa \mathrm{B})$. All cells were cotransfected with the control CMV- $\beta$-galactosidase plasmid. Following $16 \mathrm{~h}$ treatment with $0-10 \mathrm{mM}$ aspirin, luciferase and $\beta$-galactosidase assays were performed on cell lysates and relative luciferase activity calculated. The graphs represent three independent experiments and the bars on the graphs are standard error bars.

This work consolidates our previous findings that aspirininduced apoptosis occurs after $\mathrm{I} \kappa \mathrm{B}$ degradation, $\mathrm{NF} \kappa \mathrm{B}$ nuclear translocation and repression of $\mathrm{NF} \kappa \mathrm{B}$-driven transcription. The results presented here shed further light on the complex mechanisms by which NSAIDs induce cell death in CRC. Elucidation of the mechanism lies in defining the relative contribution of putative targets to aspirin's anti-tumour activity. We found no evidence for the involvement of p53 or DNA MMR on inducing the $\mathrm{NF} \kappa \mathrm{B}$ pathway, nor on the ensuing apoptotic response. Genomic instability due to p53 or MMR dysfunction has been to shown to be associated with resistance to chemotherapeutic agents. Hence, these findings may inform rational design of novel therapeutics. In addition, since aspirin effects on $\mathrm{NF} \kappa \mathrm{B}$ and apoptosis occur in cancers arising from different genetic backgrounds, these findings are clinically relevant when considering design of chemoprevention trials, both in genetically predisposed individuals with defective MMR and in low and moderate

\section{REFERENCES}

Baker SJ, Fearon ER, Nigro JM, Hamilton SR, Preisinger AC, Jessup JM, vanTuinen P, Ledbetter DH, Barker DF, Nakamura Y (1989) Chromosome 17 deletions and p53 gene mutations in colorectal carcinomas. Science 244: 217-221

Baker SJ, Preisinger AC, Jessup JM, Paraskeva C, Markowitz S, Willson JK, Hamilton S, Vogelstein B (1990) p53 gene mutations occur in combination with $17 \mathrm{p}$ allelic deletions as late events in colorectal tumorigenesis. Cancer Res 50: 7717-7722

Barkett M, Gilmore TD (1999) Control of apoptosis by Rel/NF-kappaB transcription factors. Oncogene 18: 6910-6924

Boland CR, Thibodeau SN, Hamilton SR, Sidransky D, Eshleman JR, Burt RW, Meltzer SJ, Rodriguez-Bigas MA, Fodde R, Ranzani GN, Srivastava S (1998) A National Cancer Institute Workshop on microsatellite instability for cancer detection and familial predisposition: development of international criteria for the determination of microsatellite instability in colorectal cancer. Cancer Res 58: 5248-5257

Brown SR, Finan PJ, Bishop DT (1998) Are relatives of patients with multiple HNPCC spectrum tumours at increased risk of cancer? [see comments]. Gut 43: 664-668

Bunz F, Hwang PM, Torrance C, Waldman T, Zhang Y, Dillehay L, Williams J, Lengauer C, Kinzler KW, Vogelstein B (1999) Disruption of p53 in human cancer cells alters the responses to therapeutic agents. J Clin Invest 104: $263-269$

Campbell KJ, Rocha S, Perkins ND (2004) Active repression of antiapoptotic gene expression by RelA(p65) NF-kappa B. Mol Cell 13: $853-865$ risk populations, since 53 mutational events are important during development and progression of colorectal neoplasia.

\section{ACKNOWLEDGEMENTS}

We are grateful to Professor B Vogelstein (Johns Hopkins University, Baltimore) for the HCT-116 $\mathrm{p}^{\mathrm{p3}-/-}$ cell line and to Professor CR Boland (University of California San Diego, La Jolla) for the HCT- $116^{+ \text {chr3 }}$ cell line. We would also like to thank Professor R Hay (University of St Andrews, Scotland) for the I $\kappa \mathrm{B} \alpha$ antibody and 3enhancer CON-A luciferase reporter constructs. The work was supported by grants from the Scottish Executive Chief Scientist's Office (K/MRS/50/C2719 and CZB/4/41) and the AICR $(02-330)$. LAS is a Caledonian Research Fellow. The Colon Cancer Genetics Group laboratories are funded by a Programme Grant from Cancer Research UK (C348/A3758).
Charalambous D, O'Brien PE (1996) Inhibition of colon cancer precursors in the rat by sulindac sulphone is not dependent on inhibition of prostaglandin synthesis. J Gastroenterol Hepatol 11: 307-310

Cottu PH, Muzeau F, Estreicher A, Flejou JF, Iggo R, Thomas G, Hamelin R (1996) Inverse correlation between RER+ status and p53 mutation in colorectal cancer cell lines. Oncogene 19(13): 2727-2730

Din FV, Dunlop MG, Stark LA (2004) Evidence for colorectal cancer cell specificity of aspirin effects on NFkappaB signalling and apoptosis. $\mathrm{Br} J$ Cancer 19(91): $381-388$

Elder DJ, Halton DE, Hague A, Paraskeva C (1997) Induction of apoptotic cell death in human colorectal carcinoma cell lines by a cyclooxygenase-2 (COX-2)-selective nonsteroidal anti-inflammatory drug: independence from COX-2 protein expression. Clin Cancer Res 3: $1679-1683$

Epinat JC, Gilmore TD (1999) Diverse agents act at multiple levels to inhibit the Rel/NF-kappaB signal transduction pathway. Oncogene 18: 6896-6909

Goel A, Chang DK, Ricciardiello L, Gasche C, Boland CR (2003) A novel mechanism for aspirin-mediated growth inhibition of human colon cancer cells. Clin Cancer Res 9: 383-390

Goldberg Y, Nassif II, Pittas A, Tsai LL, Dynlacht BD, Rigas B, Shiff S (1996) The anti-proliferative effect of sulindac and sulindac sulfide on HT-29 colon cancer cells: alterations in tumor suppressor and cell cycleregulatory proteins. Oncogene 12: 893-901

Hanif R, Pittas A, Feng Y, Koutsos MI, Qiao L, Staiano-Coico L, Shiff SI, Rigas B (1996) Effects of nonsteroidal anti-inflammatory drugs on 
proliferation and on induction of apoptosis in colon cancer cells by a prostaglandin-independent pathway. Biochem Pharmacol 52: 237-245

Herman JG, Umar A, Polyak K, Graff JR, Ahuja N, Issa JP, Markowitz S, Willson JK, Hamilton SR, Kinzler KW, Kane MF, Kolodner RD, Vogelstein B, Kunkel TA, Baylin SB (1998) Incidence and functional consequences of hMLH1 promoter hypermethylation in colorectal carcinoma. Proc Natl Acad Sci USA 95: 6870-6875

Honma M, Momose M, Tanabe H, Sakamoto H, Yu Y, Little JB, Sofuni T, Hayashi M (2000) Requirement of wild-type p53 protein for maintenance of chromosomal integrity. Mol Carcinog 28: 203-214

Koi M, Umar A, Chauhan DP, Cherian SP, Carethers JM, Kunkel TA, Boland CR (1994) Human chromosome 3 corrects mismatch repair deficiency and microsatellite instability and reduces $N$-methyl- $N^{\prime}$-nitro$\mathrm{N}$-nitrosoguanidine tolerance in colon tumor cells with homozygous hMLH1 mutation [published erratum appears in Cancer Res 1995 Jan 1;55(1):201]. Cancer Res 54: 4308-4312

Kralj M, Kapitanovic S, Kovacevic D, Lukac J, Spaventi S, Pavelic K (2001) Effect of the nonsteroidal anti-inflammatory drug indomethacin on proliferation and apoptosis of colon carcinoma cells. J Cancer Res Clin Oncol 127: $173-179$

Kuismanen SA, Holmberg MT, Salovaara R, de la CA, Peltomaki P (2000) Genetic and epigenetic modification of MLH1 accounts for a major share of microsatellite-unstable colorectal cancers. Am J Pathol 156: $1773-1779$

Marnett LJ, DuBois RN (2002) COX-2: a target for colon cancer prevention. Annu Rev Pharmacol Toxicol 42: 55-80

O'Connor PM, Jackman J, Bae I, Myers TG, Fan S, Mutoh M, Scudiero DA, Monks A, Sausville EA, Weinstein JN, Friend S, Fornace Jr AJ, Kohn KW (1997) Characterization of the p53 tumor suppressor pathway in cell lines of the National Cancer Institute anticancer drug screen and correlations with the growth-inhibitory potency of 123 anticancer agents. Cancer Res 57: 4285-4300

Piazza GA, Rahm AK, Finn TS, Fryer BH, Li H, Stoumen AL, Pamukcu R, Ahnen DJ (1997) Apoptosis primarily accounts for the growth-inhibitory properties of sulindac metabolites and involves a mechanism that is independent of cyclooxygenase inhibition, cell cycle arrest, and p53 induction. Cancer Res 57: 2452-2459

Piazza GA, Rahm AL, Krutzsch M, Sperl G, Paranka NS, Gross PH, Brendel K, Burt RW, Alberts DS, Pamukcu R (1995) Antineoplastic drugs sulindac sulfide and sulfone inhibit cell growth by inducing apoptosis. Cancer Res 55: 3110-3116

Qiao L, Hanif R, Sphicas E, Shiff SJ, Rigas B (1998) Effect of aspirin on induction of apoptosis in HT-29 human colon adenocarcinoma cells. Biochem Pharmacol 55: 53-64

Ribic CM, Sargent DJ, Moore MJ, Thibodeau SN, French AJ, Goldberg RM, Hamilton SR, Laurent-Puig P, Gryfe R, Shepherd LE, Tu D, Redston M,
Gallinger S (2003) Tumor microsatellite-instability status as a predictor of benefit from fluorouracil-based adjuvant chemotherapy for colon cancer. N Engl J Med 349: 247-257

Roff M, Thompson J, Rodriguez MS, Jacque JM, Baleux F, ArenzanaSeisdedos F, Hay RT (1996) Role of IkappaBalpha ubiquitination in signal-induced activation of NFkappaB in vivo. J Biol Chem 271: $7844-7850$

Ruschoff J, Wallinger S, Dietmaier W, Bocker T, Brockhoff G, Hofstadter F, Fishel R (1998) Aspirin suppresses the mutator phenotype associated with hereditary nonpolyposis colorectal cancer by genetic selection. Proc Natl Acad Sci USA 95: 11301-11306

Samowitz WS, Holden JA, Curtin K, Edwards SL, Walker AR, Lin HA, Robertson MA, Nichols MF, Gruenthal KM, Lynch BJ, Leppert MF, Slattery ML (2001) Inverse relationship between microsatellite instability and K-ras and p53 gene alterations in colon cancer. Am J Pathol 158: $1517-1524$

Shao J, Fujiwara T, Kadowaki Y, Fukazawa T, Waku T, Itoshima T, Yamatsuji T, Nishizaki M, Roth JA, Tanaka N (2000) Overexpression of the wild-type p53 gene inhibits NF-kappaB activity and synergizes with aspirin to induce apoptosis in human colon cancer cells. Oncogene 19: $726-736$

Stark L, Din FVN, Dunlop MG (2000) Aspirin-induced apoptosis of colorectal cancer cells is caused by nuclear translocation of repressive NF $\kappa$ B complexes. Proc Am Assoc Cancer Res 41: 495

Stark LA, Din FVN, Zwacka RM, Dunlop MG (2001) Aspirin-induced activation of the $\mathrm{NF} \kappa \mathrm{B}$ signaling pathway: a novel mechanism for aspirin-mediated apoptosis in colon cancer cells. FASEB J 15: 1273-1275

Thun MJ, Namboodiri MM, Calle EE, Flanders WD, Heath CWJ (1993) Aspirin use and risk of fatal cancer [see comments]. Cancer Res 53: $1322-1327$

Veigl ML, Kasturi L, Olechnowicz J, Ma AH, Lutterbaugh JD, Periyasamy S, Li GM, Drummond J, Modrich PL, Sedwick WD, Markowitz SD (1998) Biallelic inactivation of hMLH1 by epigenetic gene silencing, a novel mechanism causing human MSI cancers. Proc Natl Acad Sci USA 95: $8698-8702$

Webster GA, Perkins ND (1999) Transcriptional cross talk between NFkappaB and p53. Mol Cell Biol 19: 3485-3495

Weller M (1998) Predicting response to cancer chemotherapy: the role of p53. Cell Tissue Res 292: 435-445

Wu H, Lozano G (1994) NF-kappa B activation of p53. A potential mechanism for suppressing cell growth in response to stress. J Biol Chem 269: 20067-20074

Yamamoto H, Itoh F, Fukushima H, Hinoda Y, Imai K (1999) Overexpression of cyclooxygenase-2 protein is less frequent in gastric cancers with microsatellite instability [In Process Citation]. Int J Cancer 84: $400-403$ 